\title{
Index to the Authors of Volume 66
}

A

ABE F $\quad 176$

ADACHI K, Igoshi A and Murata M: Analyses of Factors Affecting the Browning of Model Processed Cheese during Storage 364

Ago Y 207

AIBA N 319

AKASHI K 114

AKHILA M 93

AKIYAMA N 128

AL-JAWALDEH A 389

AL-NADHARI S 10

ALARFAJ AA 10

AlmadA MORDV, ALMEIDA ACF, UED FDV, MATHIAS

MG, Coelho-Landell CDA, Salomao RG, Toffano RBD, Camarneiro JM, Hillesheim E, Barros TTD, CAmelo-Junior JS, Moco S, Kaput J and Monteiro JP: Metabolic Groups Related to Blood Vitamin Levels and Inflammatory Biomarkers in Brazilian Children and Adolescents $\quad 515$

ALMEIDA ACF 515

Ambar, Asghar M, Ameen F, Al-Nadhari S, WASEem A, YaQOOB M, Alarfaj AA and NABI A: A Flow Injection Chemiluminescence Method for the Determination of Retinol in Pharmaceutical Formulations by Using Luminol-Diperiodatoargentate(III) Reaction 10

AMEEN F 10

AOI W 261

AOKI H 296

AOYAMA M 237

ARAKAWA H 60

ARAKI Y, IDA Y, NonAKa M, YoshizAKI Y, FuJII A, NAGANO $\mathrm{M}$ and KanOUCHI H: The Induction of Heat Shock Protein 70 after Oral Administration of Concentrated Brewed Rice Vinegar Kurozu in Mice 478

ARYASRI AS 93

ASAHI R 561

ASAMI Y: 128

ASGHAR M 10

AZABU H 60

B

BADAM R 93

BAO Q 300

BARROS TTD $\quad 515$

\section{C}

Cai Q, Li Y, Lyu F, Zhou M, Lu K, TANG X, Ren D, BaO Q, WANG D and LI Y: Effects of All-Trans Retinoic Acid on the Optimization of Synovial Explant Induced by Tumor Necrosis Factor Alpha 300

CAMARNEIRO JM 515

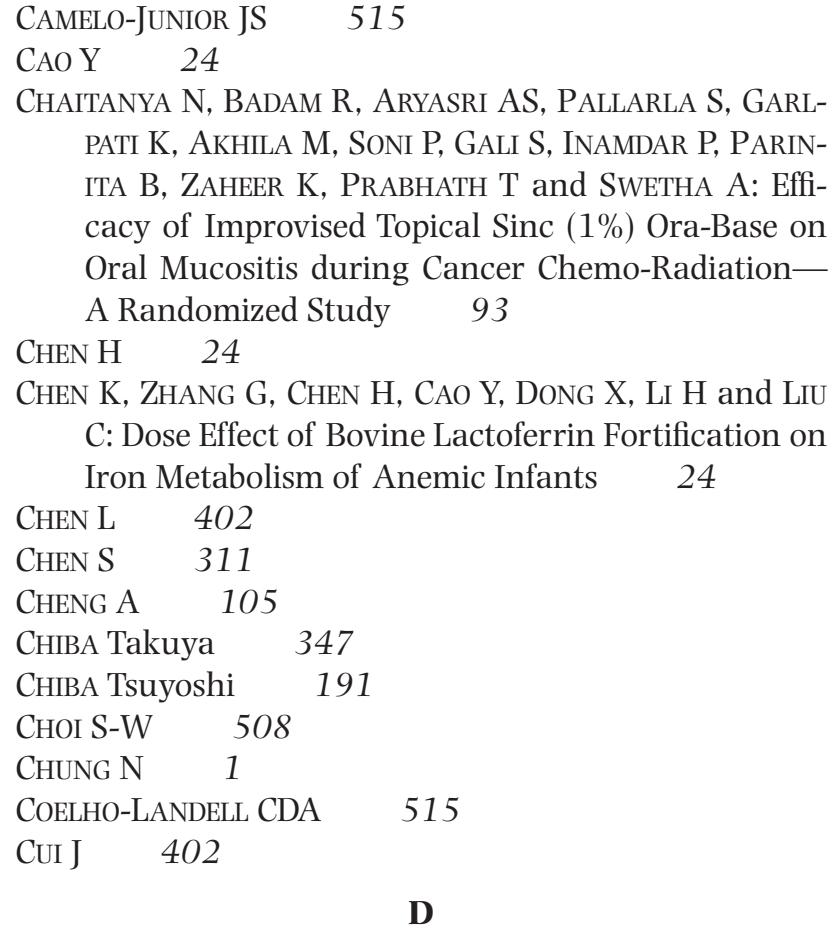

Chaitanya N, Badam R, Aryasri AS, Pallarla S, GARLPATI K, AKHILA M, SONI P, GALI S, INAMDAR P, PARINita B, Zaheer K, Prabhath T and Swetha A: Efficacy of Improvised Topical Sinc (1\%) Ora-Base on Oral Mucositis during Cancer Chemo-RadiationA Randomized Study 93

CHEN H 24

Chen K, Zhang G, Chen H, Cao Y, Dong X, Li H and LiU $\mathrm{C}$ : Dose Effect of Bovine Lactoferrin Fortification on Iron Metabolism of Anemic Infants 24

CHEN L 402

CHEN S 311

CHeng A 105

CHIBA Takuya 347

CHIBA Tsuyoshi 191

CHOI S-W 508

Chung N 1

COELHO-LANDELL CDA 515

CUI J 402

D

DENG D 311

Dillon KN, Shariffi B, Thompson B, Steele R and Kim J-K: Effects of Acute Grape Seed Extract Supplementation on Hemodynamics in Normal Body Weight and Obese Males $\quad 427$

DogGui R 389

DONG X 24

\section{$\mathbf{E}$}

$\begin{array}{lc}\text { EL NOUBY FH } & 526 \\ \text { EL-HAKEIM EH } & 526 \\ \text { ELGAMAL DA } & 526\end{array}$

Elrayah EE, Rogers L, Doggui R and Al-JaWALDEH A: Vitamin D Insufficiency and Deficiency in the Eastern Mediterranean Region (EMR)-Misconceptions in Public Health Practice: A Scoping Review 2019$2020 \quad 389$

\section{$\mathbf{F}$}

FAN D 396

FANG R 311

FENG P 409

Fu C, Yang Y, Kumrungsee T, Kimoto A, IZu H and Kato $\mathrm{N}$ : Low-Dose Ethanol Has Impacts on Plasma Levels of Metabolites Relating to Chronic Disease Risk in SAMP8 Mice 553

FUJII A 478

Fujimi TJ, Sate M, Tsuchiya M, Hirono M, Asahi R, SuzuKi R, NAKaJima S, YoKOYAma H, MatsuUra T and KANZAWA N: Gene Expression and Histochemical Analyses in the Fatty Livers of Rats Fed a Histidine-Excess Diet 561 


$\begin{array}{lc}\text { FUJITA M } & 502 \\ \text { FUJITA Y } & 158 \\ \text { FUKAO M } & 449 \\ \text { FUKAYA T } & 449 \\ \text { FUKIYA S } & 571\end{array}$

FuKUdA Y, YAmamoto S, HatakeYama A, Nishida K and KAMEDA M: A Study of Dietary and BMI Changes Over Time in Mothers of Children with Food Allergies 119

$\begin{array}{lc}\text { FUKUHARA I } & 417 \\ \text { FUKUI M } & 261 \\ \text { FUKUZAWA K } & 200\end{array}$

\section{G}

$\begin{array}{lr}\text { GALI S } & 93 \\ \text { GARLPATI K } & 93 \\ \text { GOMA SH } & 526 \\ \text { GOTO A } & 587 \\ \text { Goto T } & 176 \\ \text { GuI S } & 409\end{array}$

$\mathbf{H}$

$\begin{array}{lc}\text { HAN J-S } & 1 \\ \text { HANAI M } & 86 \\ \text { HANZAWA F } & 19 \\ \text { HARA H } & 488 \\ \text { HARADA K } & 545\end{array}$

Hasegawa Y, Tsutsumi C, Mitsuhashi F, Kimura N, IWABUCHI Y, SAKAMOTO S and ISHIKAWA-TAKATA K: The Effect of Freeze-Drying Pretreatment on the Accuracy of Near Infrared Spectroscopic Food Analysis to Predict the Nutritive Values of Japanese Cooked Foods 441

HASHIMOTO K 75

HATAKEYAMA A 119

HATAKEYAMA Y 417

HATANAKA T 357

HAYASHI I 246

HAYASHI M 488

HIBINO T 339

HIGASHI A 545

HIGASHIDA K 41

HILLESHEIM E 515

Hino S, Nishimura N and Morita T: Hairy Region Concentrate of Pectin Strongly Stimulates Mucin Secretion in HT-29MTX Cells, but to a Lessor Degree in Rat Small Intestine $\quad 331$

HIRAI A $\quad 48,481$

HIRANUMA M 60

HIRONO M 561

HIROYAMA N 114

HISAJIMA T 255

HOMMA C 587

HONDA M 339

HORIBA N 60

HORIO F 19

HOSAKA T 583

HosHI M 587

Hoshino K, Kugo H, Miyamoto C, Hashimoto K, Murase H, Mizuno M, Moriyama T and Zaima N: The Seed
Coat Extract of Black Soybean Decreases NicotineInduced Vascular Fiber Degradation by Suppressing Matrix Metalloproteinase 2 Expression $\quad 75$ HOSOKAWA N 60

HOSONO N 587

Hu L 105

Huang F, Liu Q, Zhang Q, Wan Z, Hu L, Xu R, Cheng A, LV Y and WANG L: Sex-Specific Association between Serum Vitamin D Status and Lipid Profiles: A CrossSectional Study of a Middle-Aged and Elderly Chinese Population 105

Huang H, Nakamura T, Yasuzawa T and Ueshima S: Effects of Coriandrum sativum on Migration and Invasion Abilities of Cancer Cells $\quad 468$

HUANG Y-C 386

HWANG $\mathrm{H}$

\section{I}

IBRAHIM AK $\quad 526$

IBRAHIM MA 526

ICHIDA Y, HOSOKAWA N, TAKEMOTO R, KoIKe T, NAKAtogawa T, Hiranuma M, Arakawa H, Miura Y, Azabu H, OHтомо S and Horiba N: Significant Species Differences in Intestinal Phosphate Absorption between Dogs, Rats, and Monkeys 60

IDA Y 478

IDRISS NK, Selim ZI, El-HaKeIM EH, El Nouby FH, IBRAHIM AK, SAYYed HG, Elgamal DA, IBrAhim MA, KAMAL D and GOMA SH: Is There a Feasible Link between Vitamin D Receptor Genotypic and Allelic Frequencies with Analytical Biomarkers of Rheumatoid Arthritis Disease? $\quad 526$

IgOSHI A 364

IIDA N 41

IKARI K 219

IKEDA S, TAKAHASHI S, SUZUKI N, HANZAWA F, HORIO F and ODA H: Gut Microbiota Is Not Involved in the Induction of Acute Phase Protein Expression Caused by Vitamin C Deficiency 19

IKEGAMI Y 237

IKI M 158

IMAI E 32

IMAI N 432

INABA H 587

INAMDAR P 93

INOUE $\mathrm{S} \quad 41$

IRIE T 449

IRISAWA Y 449

ISHIGAMI A 296

ISHIHARA K, TANIGUCHI H, AKIYAMA N and AsAmi Y: Easy to Swallow Rice Cake as a Carbohydrate Source during Endurance Exercise Suppressed Feelings of Thirst and Hunger without Changing Exercise Performance 128

ISHII N 289

ISHIKAWA $S \quad 381$

ISHIKAWA-TAKATA K, TANAKA S, PARK J, MIYACHI M, Morita A, Aiba N and Watanabe S: Energy Expenditure in Free-Living Japanese People with Obesity and Type 2 Diabetes, Measured Using the Doubly- 


\begin{tabular}{lc}
\multicolumn{3}{c}{ Labeled Water Meth } \\
ISHIKAWA-TAKATA K \\
ISHIMOTO K & 207 \\
ISHIZAWA M & 370 \\
IWABUCHI Y & 441 \\
IWAMONOTO H & 54 \\
IWAMOTO Y & 381 \\
IZU H & 553 \\
IZUMI Y & 185
\end{tabular}

\section{J}

JANG D-G, RYU S-Y, PARK J and CHOI S-W: Low Muscle Mass Is Associated with Lower 25-Hydroxyvitamin D Level in All Age Groups of South Korean Adults: The 2009-2010 Korea National Health and Nutrition Examination Surveys (KNHANES) 508 JiN X 409

\section{$\mathbf{K}$}

$\begin{array}{lc}\text { KADOWAKI M } & 462 \\ \text { KAGEYAMA H } & 339 \\ \text { KAMAL D } & 526 \\ \text { KAMEDA M: } & 119 \\ \text { KAMEI Y } & 502 \\ \text { KANAHORI S } & 417\end{array}$

KANG X, CUI J, Zhang M, WANG Y, TANG W and Chen L: Maternal Level of 25-Hydroxyvitamin D during Pregnancy Associated with Risk of Type 1 Diabetes in the Offspring, a Meta-Analysis $\quad 402$

\begin{tabular}{lcc} 
KANOUCHI H & 478 \\
KANZAWA N & 561 \\
KAPUT J & 515 & \\
KARIYAZONO H & 284 \\
KATAHIRA R & 375 \\
KATO N & 553 \\
KATO S & 370 \\
KAWADA T & \multicolumn{2}{c}{176}
\end{tabular}

KaWaKami K, Moritani C, Hatanaka T, Suzaki E and TsuBoI S: Hepatoprotective Activity of Yellow Chinese Chive against Acetaminophen-Induced Acute Liver Injury via Nrf2 Signaling Pathway 357

KAWANISHI M 325

KAYASHITA J 224

KIM J 1

KIM J-K 427

KIM YH 98

KIMOTO A 553

KIMURA M 289

KIMURA N 441

KIRA R 325

KISHIMOTO N 289

Kishimoto Yoshimi, Saita E, Taguchi C, AoYAma M, IKEGAMI Y, OHMORI R, KONDO K and MOMIYAMA Y: Associations between Green Tea Consumption and Coffee Consumption and the Prevalence of Coronary Artery Disease 237

Kisнimoto Yuka 417

KitagaWa A, OHTA Y, OHashi K, Yashiro K and FukUZAWA K: Effect of High Fructose-Induced Metabolic Syndrome on Tissue Vitamin E and Lipid Peroxide
Levels in Rats 200

KitagaWA Machiko, NaKagaWA S, SuZuKi T, Kishimoto Y, KANAHORI S, HATAKEYAMA Y, TOMITA S and FUKUHARA I: Visceral Fat-Reducing Effect and Safety of Continuous Consumption of Beverage Containing Resistant Maltodextrin: A Randomized, DoubleBlind, Placebo-Controlled, Parallel-Group Clinical Trial 417

KITAGAWA Mari 278

KITAI S 41

Kiтo A and ImAi E: The Association with Dietary Patterns and Risk of Anemia in Japanese Elderly 32

Kobayashi M, MiURA T, MiURA K, HiROYAMA N and AKASHI $\mathrm{K}$ : Effect of a Moderate Carbohydrate-Restricted Diet on DPP-4 Inhibitor Action among Individuals with Type 2 Diabetes Mellitus: A 6-Month Intervention Study 114

KOBAYASHI T 185

KobaYASHI Yuki, IMAI $\mathrm{N}$ and UenISHI K: Attempt to Determine the Cut-Off Value of Serum Ferritin for Iron Deficiency in Male College Student Runners 432

KOBAYASHI Yukiko 261

KODERA M 48,481

KOHRI T, KIRA R, MYoJIN C, KAWANISHI M and TOMOTAKE $\mathrm{H}$ : Enhancing Effects of Herbs on the Salty Taste Perception of Saline 325

KOIKE T 60

KOJIMA M 545

Koma R and Terasawa N: Pre-Exercise Glucose Ingestion May Improve Endurance Capacity in East Asian Student Athletes with Lower Blood Glucose Response 150

KONDO K 237

KONDO Y 296, 347

Korteerakul C, Honda M, Ngoennet S, Hibino T, WAdITEE-SIRISATTHA R and KageYAMA H: Antioxidative and Antiglycative Properties of Mycosporine-Like Amino Acids-Containing Aqueous Extracts Derived from Edible Terrestrial Cyanobacteria 339

KoUdA K, IKI M, FujtTA Y, NAKAMURA H, UENISHI K, OHARA $\mathrm{K}$ and NishIYAMA T: Calcium Intake and Bone Mineral Acquisition during the Pubertal Growth Spurt: Three-Year Follow-Up of the Kitakata Kids Health Study in Japan 158

KuBO A 289

KugO H 75

KuMODE M 278

KumRUngSEE T 553

KuO C-Y, HuAng Y-C, LIN K-J and Tsai T-Y: Vitamin D Deficiency Is Associated with Severity of Dry Eye Symptoms and Primary Sjögren's Syndrome: A Systematic Review and Meta-Analysis $\quad 386$

KuROISHI T and SugAWARA S: Metabolomic Analysis of Liver from Dietary Biotin Deficient Mice $\quad 82$

KUSUNOKI T 545

KUWABARA A 213,497

Kuwabara A, Nagae A, Kitagawa M, Tozawa K, Kumode $\mathrm{M}$ and TANAKA K: Nutritional Therapy with Vitamin $K_{1}$ Is Effective in the Improvement of Vitamin K 
Status and Bone Turnover Markers in Patients with Severe Motor and Intellectual Disabilities 278

\section{L}

LEE C-H 1

LEE JS and KIM YH: Vitamin D Status and Related Factors among Korean Stroke Survivors: A Nationwide Population-Based Study $\quad 98$

LI C 311

LI H 24

LI M $\quad 577$

LI T 311

LI Yanchao 168

LI Yulin 300

Li Yun 300

LIANG X 456

LIM K 1

LIN K-J 386

LIU B, FAN D and YIN F: The Relationship between Vitamin D Status and Visceral Fat Accumulation in Males with Type 2 Diabetes 396

LIU C 24

LIU Q 105

LiU T, Sun Y, Yang S and Liang X: Inhibitory Effect of Selenium on Esophagus Cancer Cells and the Related Mechanism 456

Lu K 300

LU X 409

LU Y 536

LUO J 311

$\mathrm{LV} \mathrm{Y} \quad 105$

LYU F 300

\section{M}

MaETA A, Matsushima M, KatahiRA R and TAKAHASHI K: Retinoic Acid Ameliorates the Severity of Food Allergy under Allergen Exposure in a Mouse Model with Food Allergy $\quad 375$

\begin{tabular}{lcc} 
MAKISHIMA M & \multicolumn{2}{c}{370} \\
MAOKA T & 488 & \\
MASUDA Y & 289 \\
MATHIAS MG & \multicolumn{2}{c}{515} \\
MATSUO T & 261 \\
MATSUSHIMA M & 375 \\
MATSUURA T & 561 \\
MIKI S 207 &
\end{tabular}

MiNATO-INOKAWA S, HAYASHI I, NiRENGI S, YAMAGUCHI K, TAKAKURA K, SAKANE N and NAGAI N: Association of Dietary Change during Pregnancy with Largefor-Gestational Age Births: A Prospective Observational Study 246

MISAWA E 176

MITSUHASHI F 441

MIURA K 114

MIURA T 114

MIURA Y 60

MIYACHI M 319

MIYAMOTO C 75

МIYAMOTO M 587

MIYAZAKI K 270
MizunO M 75

MochizuKi T, YANO K, IKARI K and OKAZAKI K: Factors Associated with Nutrition of Japanese Patients with Rheumatoid Arthritis Who Underwent the Mini Nutritional Assessment (MNA), Health Assessment Questionnaire Disability Index, and Body Composition Assessment by Bioelectrical Impedance Analysis 219

MOCO S 515

MOMIYAMA Y 237

MONTEIRO JP 515

MORITA A 319

MORITA S 54

MORITA T 331

MORITANI C 357

Moriyama T, Yano E, Zaima N, Miyazaki K, Shirotsuki K, Sato A and SaWAguchi M: Development of Pretreatment Protocols for Determination of Soybean $\beta$-Conglycinin in Processed Soybean Foods Using Commercial ELISA Kits 270

MORIYAMA T 75

MURAKAMI T 41

MURASE $\mathrm{H} \quad 75$

MURATA M 191, 364

MYOJIN C 325

\section{$\mathbf{N}$}

NABESHIMA K 176

NABI A 10

NAGAE A 278

NAGAI K 381

NAGAI N 246

NAGANO M 478

NAgATA Y, YAMAMOTO T and KADOWAKI M: Ginger Increases ALDH1A1 Expression and Enhances Retinoic Acid Signaling in a Human Colonic Epithelial Cell Line $\quad 462$

NAKADA M 48,481

NAKAGAWA Shinsaku 207

NAKAGAWA Shinsuke 417

NAKAi N, KitAi S, IIDA N, InOUE S, NAKATA K, Murakami $\mathrm{T}$ and HigASHIDA K: Induction of Autophagy and Changes in Cellular Metabolism in Glucose Starved C2C12 Myotubes 41

NAKAI S, FuJITA M and KAMEI Y: Health Promotion Effects of Soy Isoflavones $\quad 502$

NAKAJIMA K, OISO S and KARIYAZONO H: Brain-Derived Neurotrophic Factor Up-Regulation by the Methanol Extract of Foxtail Millet in Human Peripheral Cells 284

NAKAJIMA S 561

NAKAMURA H 158

NAKAMURA $S$, MAOKA T, TSUJI S, HAYASHI M, SHIMAZAWA $\mathrm{M}$ and HARA H: Central Nervous System Migration of Astaxanthin and Adonixanthin Following Their Oral Administration in Cynomolgus Monkeys 488

NAKAMURA Takako 261

NAKAMURA Tomomi 468

NAKAMURA Yasushi 261 
NAKAMURA Yuta 207

NAKATA K 41

NAKATOGAWA T 60

NAKATSU Y, NIIDA S, TANAKA K, TAKENAKA S and KUWABARA A: The Relationship between Serum Vitamin E Level and Risk Factors for Arteriosclerosis in Japanese Postmenopausal Women 213

$\begin{array}{lc}\text { NANBA F } & 571 \\ \text { NGOENNET S } & 339 \\ \text { NGUYEN LT } & 224 \\ \text { NIIDA S } & 213 \\ \text { NIKAWA T } & 449 \\ \text { NIRENGI S } & 246 \\ \text { NISHIDA K } & 119\end{array}$

NishidA S, ISHIZAWA M, KATO S and MAKISHIMA M: Vitamin D Receptor Deletion Changes Bile Acid Composition in Mice Orally Administered Chenodeoxycholic Acid 370

NISHIJIMA C 191

NISHIMURA N 331

NISHIMURA S 86

Nishiumi S, IZUMI Y, KoBAYAshi T and Yoshida M: Possible Involvement of Lipids in the Effectiveness of Kombu in Individuals with Abnormally High Serum Triglyceride Levels $\quad 185$

NISHIYAMA T 158

NISHIZAKI Y 289

NISHIZONO S 347

NONAKA M 478

\section{$\mathbf{O}$}

OARADA M 449

Obata F, Yu G, OHTA H, Susuki N, Shimazaki M, Nishimura $S$ and HANAi M: Dietary Cystine Ameliorates Defects in Spermatogenesis via Testosterone Production Induced by Protein Deficiency and Darkness in Rats 86

ODA H 19

Odo S, TANabe K, Yohda M and Yamauchi M: LiverOriented Acute Metabolic Effects of a Low Dose of L-Carnitine under Fat-Mobilizing Conditions: Pilot Human Clinical Trial 136

OGAWA R 381

OHARA K 158

OHASHI K 200

OHATA Y 347

OHKUBO T 68

OHMORI R 237

OHTA H 86

OHTA Y 200

Oнтомо S 60

OISHI S 381

OISO S 284

OKАМОTO S 261

OKAZAKI K 219

OKI T 68

OSAWA T 48,481

OTANi S, Miki S, NAKAMURA Y, Ishimoto K, Ago Y and NAKAGAWA S: Improved Bioavailability of $\beta$-Carotene by Amorphous Solid Dispersion Technology in
Rats 207

OTOMARU K, OGAWA R, OISHI S, IWAMOTO Y, ISHIKAWA S and NAGAI K: Effect of Beta-Carotene Supplementation on the Peripheral Blood Leukocyte Population in Japanese Black Calves $\quad 381$

OTSUKI N 583

\section{$\mathbf{P}$}

\begin{tabular}{lcr} 
PALLARLA S & \multicolumn{2}{c}{93} \\
PARINITA B & 93 & \\
PARK EY & 261 & \\
PARK H-Y & 1 & \\
PARK Jong & 508 & \\
PARK Jonghoon & 1,319
\end{tabular}

PARK M-Y, Kim J, Chung N, PARK H-Y, Hwang H, HaN J-S, SO J-M, LEE C-H, PARK J and LIM K: Dietary Factors and Eating Behaviors Affecting Diet-Induced Thermogenesis in Obese Individuals: A Systematic Review 1

Peng P, Deng D, Chen S, Li C, Luo J, Romeo A, Li T, Tang $\mathrm{X}$ and Fang R: The Effects of Dietary Porous Zinc Oxide Supplementation on Growth Performance, Inflammatory Cytokines and Tight Junction's Gene Expression in Early-Weaned Piglets 311

PRABHATH T 93

$\mathbf{R}$

$\begin{array}{lc}\text { REN D } & 300 \\ \text { ROGERS L } & 389 \\ \text { ROMEO A } & 311 \\ \text { RYU S-Y } & 508\end{array}$

$\mathbf{S}$

SAITA E 237

SAITO M 176

SAKAMOTO S 441

SAKANE N 246

SALOMAO RG 515

Santa R, MiYamoto M, Hosono N, Homma C, Hoshi M, Goto A, SATO N, SUZUKI K, InABA H and SHIBUYA K: Mastication of Hard Gumi Decreases the Gustatory Threshold for Sodium Chloride $\quad 587$

SASAKI A, NAKAMURA Y, KOBAYASHI Y, AOI W, NAKAMURA T, SHIROTA K, SuEtome N, FuKui M, Matsuo T, OKAmoto S, TAshiro Y, Park EY and Sato K: Contribution of Katsura-uri (Japan's Heirloom Pickling Melon, Cucumis melo var. conomon) at the Completely Ripe Stage to Diabetes Control 261

SATE M 561

SATO A 270

SATO K 261

SATO N 587

SATO Y 191

SAWAGUCHI M 270

SAYYED HG 526

SELIM ZI 526

SHAO M 536

SHARIFFI B 427

Shi C, WANG L, ZHou K, ShaO M, Lu Y and Wu T: Targeted Metabolomics Identifies Differential Serum 
and Liver Amino Acids Biomarkers in Rats with Alcoholic Liver Disease $\quad 536$

\begin{tabular}{lcc} 
SHIBUYA K & 587 \\
SHIMAZAKI M & \multicolumn{2}{c}{86} \\
SHIMAZAWA M & \multicolumn{2}{c}{488} \\
SHIMURA F & 224 \\
SHIRONO H & \multicolumn{2}{c}{449} \\
SHIROTA K & 261 \\
SHIROTSUKI K & \multicolumn{2}{c}{270} \\
SO J-M & \multicolumn{2}{c}{} \\
SONI P & 93 \\
SONOKI H & \multicolumn{2}{c}{54} \\
STEELE R & \multicolumn{2}{c}{427} \\
SUETOME N & \multicolumn{2}{c}{261} \\
SUGAWARA S & \multicolumn{2}{c}{82} \\
SUN Y & 456 \\
SUSUKI N & \multicolumn{2}{c}{86} \\
SUZAKI E & \multicolumn{2}{c}{357} \\
SUZUKI J & 229 \\
SUZUKI K & 587 \\
SUZUKI N & \multicolumn{2}{c}{19} \\
SUZUKI R & 561
\end{tabular}

SuzuKi S, Nishijima C, SATo Y, Umegaki K, Murata M and CHIBA T: Coleus forskohlii Extract Attenuated the Beneficial Effect of Diet-Treatment on NASH in Mouse Model 191

SuzUKI Takuto 417

SuZUKI Takuya 255

SUZUKI Taro 545

SuZUKI Toshio $\quad 571$

SWETHA A 93

\section{$\mathbf{T}$}

Tachibana N, Fukao M, Irie T, IrisaWa Y, Shirono H, OARADA M, NIKAWA T and FuKaYA T: A Diet Including Red Bell Pepper Juice and Soy Protein Suppress Physiological Markers of Muscle Atrophy in Mice 449

Tada A, Misawa E, TanaKa M, Saito M, Nabeshima K, YAMAUCHI K, ABE F, GOTO T and KAWADA T: Investigating Anti-Obesity Effects by Oral Administration of Aloe vera Gel Extract (AVGE): Possible Involvement in Activation of Brown Adipose Tissue (BAT) 176

TAGUCHI C 237

TAKAHASHI K $\quad 375$

TAKAHASHI R, YoshidA T, ToKU H, OTSUKI N and HosaKa T: Impact of Meal Timing on Postprandial Interstitial Fluid Glucose Levels in Young Japanese Females 583

TAKAHASHI S 19

TAKAKURA K 246

TAKASHIMIZU S 289

TAKebayashi J, OKI T, Tsubota-Utsugi M, OHKubo T and WatanaBe J: Antioxidant Capacities of PlantDerived Foods Commonly Consumed in Japan 68

TAKEDA Y 54

TAKEMOTO R 60

TAKENAKA S 213
TAKino Y, AOKI H, Kondo Y and Ishigami A: Acerola (Malpighia emarginata DC.) Promotes Ascorbic Acid Uptake into Human Intestinal Caco-2 Cells via Enhancing the Gene Expression of Sodium-Dependent Vitamin C Transporter $1 \quad 296$

TANABE K 136

TANAKA K, KuWABARA A and TsugaWA N: Vitamin D in the Dietary Reference Intakes for Japanese (DRIs) $2020 \quad 497$

TANAKA K 213, 278

TANAKA M 176

TANAKA S 319

TANG W 402

TANG Xiaopeng 311

TANG Xiaoyue 300

TAng Y, Feng P, Gui S, Jin X, Zhu J and Lu X: The Protective Effects of Protein-Enriched Fraction from Housefly (Musca domestica) against Aged-Related Brain Aging 409

TANIGUCHI H 128, 545

TASHIRO Y 261

TERASAWA N 150

THOMPSON B 427

TODA T 571

TOFFANO RBD 515

TOKU H 583

TOMITA S 417

TOMOTAKE H 325

TOYODA M 289

TOZAWA K 278

TrAn TP, NGUYEN LT, KAYASHITA J, SHIMURA F and YAMAмото S: Nutritional Status and Feeding Practice among Dysphagic Older Adult Inpatients in Vietnam 224

TSAI T-Y 386

TsuBoI S 357

TsubotA-UTSugi M 68

TSUCHIYA M 561

TSUGAWA N 497

TsuJI $\mathrm{S} \quad 488$

TSUTSUMI C 441

$\mathbf{U}$

$\begin{array}{lc}\text { UEBABA K } & 255 \\ \text { UED FDV } & 515 \\ \text { UENISHI K } & 158,432 \\ \text { UENO Y } & 48,481 \\ \text { UESHIMA S } & 468 \\ \text { UMEGAKI K } & 191 \\ \text { URATA N } & 289\end{array}$

\section{W}

WADITEE-SIRISATTHA R 339

WAKI H, SUZUKI T, UEBABA K and HisajIMA T: Effects of a Standardized Oligomerized-Polyphenol from Litchi chinensis Fruit Extract and Mixed Plant Extract Supplementation on Peripheral Circulation and Cold Sensitivity 255

WAN Z 105

WANG D 300 
WANG L $\quad 105,536$

WANG W 577

WANG Y 402

WANG Z, OHATA Y, WATANABE Y, YuAN Y, Yoshit Y, Kondo Y, NishIZONO S and CHIBA T: Taurine Improves Lipid Metabolism and Increases Resistance to Oxidative Stress 347

WASEEM A 10

WATANABE J 68

WATANABE M 571

WATANABE S 319

WATANABE Y 347

Wu T 536

$\mathbf{X}$

XIA Jiyi $\quad 577$

Xia Jizhu, Xia X, Wang W, Xia Jiyi and Li M: Protective Effect of Se-Methylselenocysteine on Elaidic AcidInduced Inflammation in Human Arterial Endothelial Cells $\quad 577$

XIA X 577

XIN Y 168

Xu R 105

\section{$\mathbf{Y}$}

YAEGASHI A and SuZUKI J: Effects of Evening-Only LowCarbohydrate Meal on Healthy Volunteers 229

Yamada C, Kishimoto N, URata N, Kimura M, TOYodA M, Masuda Y, TAKashimizu S, Ishit N, Kubo A and NisHIZAKI Y: Relationship between Serum Antioxidative Vitamin Concentrations and Type 2 Diabetes in Japanese Subjects 289

\begin{tabular}{|c|c|c|}
\hline YAMAGUCHI K & \multicolumn{2}{|c|}{246} \\
\hline YАMАMOTO SH & & 224 \\
\hline YАMАMOTO SH & & 119 \\
\hline YАMАMOTO T & 46 & \\
\hline YAMAUCHI K & 17 & \\
\hline YAMAUCHI M & 13 & \\
\hline
\end{tabular}

YANG M, ZHANG D, LI Y and XIN Y: Maternal Protein Restriction Increases Autophagy in the Pancreas of Newborn Rats 168

YANG S 456

YANG Y 553

YANO E 270

\begin{tabular}{lc} 
YANO K & 219 \\
YAQOOB M & \multicolumn{1}{c}{10} \\
YASHIRO K & 200 \\
YASUZAWA T & \multicolumn{2}{c}{468} \\
YIN F & 396 \\
YOHDA M & \multicolumn{2}{c}{136} \\
YOKOTA A & 571 \\
YOKOYAMA H & 561
\end{tabular}

YoKOyama S, Kodera M, HiRAi A, NAKAdA M, UENO Y and OSAWA T: Red Clover (Trifolium pratense L.) Sprout Prevents Metabolic Syndrome 48

Yokoyama S, Kodera M, Hirai A, NaKada M, Ueno Y and OSAWA T: Benzyl Isothiocyanate Produced by Garden Cress (Lepidium sativum) Prevents Accumulation of Hepatic Lipids 481

YoSHIDA M 185

YOSHIDA T 583

Yoshit K, Kojima M, Kusunoki T, Suzuki T, TANiguchi H, HARADA K and Higashi A: Negative Association in Reported Dietary Energy Intake and Physique in Japanese Schoolchildren $\quad 545$

YoshiI Y 347

YoshikaWA M, MoRita S, SONOKI H, IWAMONOTO H and TAKEDA Y: Evaluation of Protein Requirements Using the Indicator Amino Acid Oxidation Method 54

Yoshioka H, WATANabe M, NANBA F, SUZUKi T, FuKiYA S, YокотA A and TODA T: Administration of Cholic Acid Inhibits Equol Production from Daidzein in Mice $\quad 571$

YOSHIZAKI Y 478

Yu G 86

YUAN Y 347

$\begin{array}{ll}\text { ZAHEER K } & 93 \\ \text { ZAIMA N } & 75,270 \\ \text { ZHANG D } & 168 \\ \text { ZHANG G } & 24 \\ \text { ZHANG M } & 402 \\ \text { ZHANG Q } & 105 \\ \text { ZHOU K } & 536 \\ \text { ZHOU M } & 300 \\ \text { ZHU J } & 409\end{array}$

